\title{
Reply to the comment of Talwani et al. (2017) on the Sibuet et al. (2016) paper entitled "Thinned continental crust intruded by volcanics beneath the northern Bay of Bengal"
}

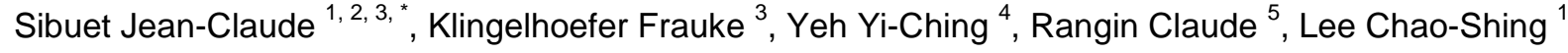

${ }^{1}$ Institute of Applied Geophysics, National Taiwan Ocean University, 2 Pei-Ning Road, Keelung 202, Taiwan

244 rue du Cloître, 29280 Plouzané, France

3 Ifremer Centre de Brest, BP 70, 29280 Plouzané Cedex, France

${ }^{4}$ Department of Earth Sciences, National Central University, Chung-Li 32001, Taiwan

${ }^{5}$ Laboratoire GEOAZUR, UMR 7329 CNRS, 250 rue Albert Einstein, Sophia-Antipolis, 06560 Valbonne, France

*Corresponding author : Jean-Claude Sibuet, email address : jean.claude.sibuet@gmail.com

frauke.klingelhoefer@ifremer.fr ; yiching.yeh@gmail.com ; claude@rangin.fr ; leecs@ntou.edu.tw

\begin{abstract}
:
The northern Bay of Bengal velocity-depth profiles do not follow the velocity-depth curve of the North Atlantic volcanic margins, and only partially the Kerguelen velocity-depth curves. Deep seismic refraction and reflection profiles acquired across the Hatton bank and Feroes ridge show that the melt is intruded into the lower thinned continental crust as sills, which cross-cut the continental fabric rather than underplating as it was often assumed in the past. Compared with the SCS northern margin proxy, we still suggest that the $\mathrm{BoB}$ crust is thinned continental crust intruded by post-rifting volcanics, as also shown by the interpretation of the numerous high-quality deep MCS profiles we collected there. What was supposed to be underplating might be sills intruded through the lower thinned continental crust.
\end{abstract}

\section{Highlights}

Bay of Bengal velocity-depth profiles do not follow those of passive volcanic margins. Bay of Bengal velocity-depth profiles partially follow those of the Kerguelen plume. The northern Bay of Bengal is thinned continental crust intruded by volcanics. Sills are intruded through the thinned lower continental crust.

Keywords : Northern Bay of Bengal, Wide-angle and reflection seismic profiles, Multichannel seismic profiles, Thinned continental crust intruded by volcanics 
Thank you to Talwani et al. (2017) to acknowledge the quality of the geophysical survey which consists of three wide-angle and reflection seismic profiles acquired during our deep multichannel seismic (MCS) reflection survey $\left(10.05-\mathrm{km}\right.$ long streamer, 64 air guns with a total volume of $\left.6180 \mathrm{in}^{3}\right)$ in the 
northern Bay of Bengal (BoB) (Figure 1a) and to give us the opportunity to extend the discussion to the role of volcanic margins and plumes. In their comment, Talwani et al. (2017) assert that the northern BoB crust is typical oceanic crust similar to the volcanic passive margins of the North Atlantic volcanic province, and not thinned continental crust. In fact, Sibuet et al. (2016a) said in the title, in the abstract, in the text and in their conclusions that the crust was not thinned continental crust but thinned continental crust intruded by volcanics, the presence of volcanics increasing the observed velocity compared to the one of the thinned continental crust alone. In this reply, we will show that our refraction data do not fit the velocity trends of the North Atlantic volcanic margins as discussed by Talwani et al. (2017). We will compare our refraction results with those of the Kerguelen plume, which may have affected the deep BoB structure but also with those of the Columbian basin (Galapagos plume) and Hatton bank (Iceland plume). Deep seismic refraction and reflection profiles acquired across the Hatton bank show that the melt intruded into the lower thinned continental crust, probably as sills, cross-cut the continental fabric rather than being an 'underplate' of 100 per cent melt (White et al., 2008), as it was often assumed in the past. Finally, the northeastern South China Sea (SCS) margin proxy, where the crust is thinned continental crust intruded by volcanics, shows that the SCS crustal velocity-depth curves are similar to those of the northern BoB.

In Figure 2, the velocity-depth curve of Eldholm and Grue (EG) (1994) for the North Atlantic volcanic margins does not fit properly the velocity-depth curves of Sibuet et al. (2016a) (Figure 2a, b and c). In the EG model, the upper crust consists of $>6 \mathrm{~km}$ extrusive basaltic lavas and inter-bedded sediments with velocities increasing from 3.5-4.0 to $6.0-6.5 \mathrm{~km} / \mathrm{s}$. The EG velocity-depth curve does not fit Profile 2 over its whole crustal section and does not fit the upper 5-7 $\mathrm{km}$ of crust for Profiles 5 and 11, a problem not discussed in Talwani et al. (2017). Rather than to limit our reply to this negative assessment, we propose to compare our results to those of more pertinent features linked to mantle plumes.

The Kerguelen plume is moving from the northwest with respect to India and passed near the location of our survey 100 Ma ago (Muller et al., 1993; Whittacker et al., 2013), suggesting to compare our BoB refraction data with those of oceanic plateaus created by mantle plumes as the Kerguelen plume. Figure $2 \mathrm{~d}$ shows the comparison of the Kerguelen plume at different locations 
(Kerguelen north, Enderby basin and Broken ridge), the Galapagos plume (Columbian basin) and the Iceland plume (Hatton bank) extracted from the Ridley and Richards (2010) synthesis of wide-angle and reflection seismic data. A large spectrum of refraction results is displayed, ranging from typical oceanic crust (Columbian basin, dark green) to close to extended continental crust (Hatton bank, light blue). Thus, the large variability of plume velocity models exacerbates the non-uniqueness of the interpretation of $\mathrm{BoB}$ refraction data. For clarity, the Columbian basin results are not reported in Figure $2 \mathrm{a}, \mathrm{b}$ and $\mathrm{c}$ because their values fall within the velocity bounds of oceanic crust, which is not the case of BoB refraction velocity data. In addition, we do not display the Enderby basin velocity-depth profile (dark blue) in Figure 2a, b and c because the Kerguelen north velocity-depth profile (red) is almost identical.

In Figure 2a, the velocity-depth profiles of plumes do not fit BoB refraction velocity results, especially in terms of crustal thicknesses. In Figure $2 b$ and $c$, the velocity-depth profile of Kerguelen fits BoB refraction velocity results, except for the upper $3 \mathrm{~km}$ of crust. The Broken ridge and even more the Hatton bank display velocity-depth profiles closer to extended continental crust velocities. Using deep penetration MCS profiles and wide-angle and reflection seismic data, White et al. (2008) demonstrated that the high velocities seen at the base of the crust below the Hatton bank represent thinned continental crust intruded by sills. This view is opposed to underplating, the common way of thinking, though long time ago it was largely stated the high-velocity lower crustal (HVLC) bodies were observed in continental settings (e.g. (Meissner, 1986)). The same conclusion was drawn for the Faroes ridge located $800 \mathrm{~km}$ north of the Hatton bank (White et al., 2008), suggesting that it applies for some, if not most of margins influenced by plumes.

Figure 3a shows some of the numerous MCS and wide-angle and reflection seismic profiles collected in the northeastern corner of the SCS and shown in Figure 1b. The velocity-depth profiles, including T1 and T2 profiles (Eakin et al., 2014) are similar to those in Figure 2 and have been interpreted as thinned continental crust intruded by volcanics (McIntosh et al., 2013; Eakin et al., 2014; Lester et al., 2014; McIntosh et al., 2014; Sibuet et al., 2016b). The velocity-depth profiles belong to the northern SCS thinned continental crust distal margin velocity bounds (orange in Figure 3a) (Lester et al., 2014). For clarity, the orange bounds are not added in Figure 2, but the three BoB velocity- 
depth profiles also fall inside the same orange bounds. Compared with the BoB, the SCS sediment thickness is smaller and high-quality deep MCS profiles display continental tilted fault blocks (Figure $3 \mathrm{~d}$ and e) north of the Continentocean transition (COT) approximately located in Figure 1b. In addition, the crust is intruded by volcanic features (e.g. Figure $3 \mathrm{~d}$ and e, CMP 44,000 ) emplaced well after rifting ceased, between 24 and $17 \mathrm{Ma}$ (Sibuet et al., 2016b), as shown by uplifted sediments along the northeastern flank of the intrusion (Figure 3e). A clear extensional event existed at that time, with the occurrence of E-type MORB basalts on the northeastern SCS margin (e.g. Zhao et al. (2016)) and at the location of the white star (Figure 1b) where a 22 Ma old E-type MORB basalt was dredged (Wang et al., 2012). Following White et al. (2008) in the interpretation of their Hatton bank and Faroes ridge profiles, the interpretation of the HVLC would be sills intruded into the SCS lower thinned continental crust rather than underplating. It is the similarity between refraction and reflection data in the BoB and northeastern SCS, which drives our interpretation of refraction data in the $\mathrm{BoB}$, rather than the incomplete similarity with the Kerguelen velocity-depth profiles.

This argumentation is reinforced by the interpretation of our $3500 \mathrm{~km}$ deep MCS BoB profiles (Rangin and Sibuet, 2017): 1) The systematic west dipping crustal features imaged into the crustal basement of our study area are interpreted as the shoulders of NW facing normal faults resulting from an asymmetrical rifting (simple shear) creating a wide margin on the Burma side and a short margin on the Indian side. These NW facing normal faults shoulders cannot be all interpreted as volcanic dipping reflectors because they do not dip in opposite directions east and west of the Kerguelen plume trajectory, i.e. on the Burma and Indian sides, respectively. 2) The northern BoB basin was created by continental rifting between Valanginian, $132 \mathrm{Ma}$ ago (Bastia and Radhakrishna, 2012), and 100 Ma ago (Gibbons et al., 2013), showing that the Kerguelen plume trajectory cut across the northern $\mathrm{BoB}$ after rifting ceased, that is after the formation of the early BoB. 3) The northern prolongation of the $90^{\circ} \mathrm{E}$ ridge displays a minor positive Free-air anomaly (Sandwell et al., 2014) and no magnetic anomaly (Maus et al., 2009). It might suggest a minor partial melting associated with the Kerguelen plume head located below an already existing thinned continental crust, resulting in the presence of sills in the lower crust and minor amount of volcanics intruding the whole crust. 
In conclusion, the northern $\mathrm{BoB}$ velocity-depth profiles do not follow the EG velocity-depth curve for the North Atlantic volcanic margins, and only partially the Kerguelen velocity-depth curves. Compared with the SCS northern margin proxy, we still suggest that the BoB crust is thinned continental crust intruded by post-rifting volcanics, as also shown by the interpretation of the numerous high-quality deep MCS profiles we collected there. What was supposed to be underplating might be sills intruded through the lower thinned continental crust.

\section{Acknowledgments}

Our geophysical survey in the northern Bay of Bengal was performed under the responsibility of the Chaire de Géodynamique du Collège de France in Aix-en Provence (France), with a financial support of Total Exploration. The Bangladesh Navy provided full support at sea to assist the seismic vessel Osprey Explorer and to deploy the OBSs supported by the Institute of Applied Geosciences, National Taiwan Ocean University. MCS Profile MGL0905-10 with its interpretation were provided by Kirk McIntosh March 10, 2017. In 2009, during the TAIGER project, we participated together (K. McIntosh, J.-C. Sibuet, C.-S. Lee and Y.-C. Yeh) in the acquisition of this profile on the R/V Marcus L. Langseth. Kirk was happy to give us the permission to show this profile as we shared the common idea that the northeastern corner of the South China Sea was thinned continental crust later intruded by volcanics. He passed away June 1, 2017. Many colleagues in our Geosciences community greatly missed Kirk. We dedicate this paper to the memory of Kirk, our friend.

\section{References}

Bastia R. and Radhakrishna, M., 2012. Basin evolution and petroleum prospectively of the continental margins of India. 59, Elsevier, Oxford, UK, 409 p.

Christensen, N. I. and W. D. Mooney (1995). Seismic velocity structure and composition of the continental crust: A global view. J. Geophys. Res., 100, 9761-9788.

Dean, S. M., T. A. Minshull, R. B. Whitmarsh and K. E. Louden (2000). Deep 
structure of the ocean-continent transition in the southern Iberia Abyssal Plain from seismic refraction profiles: The IAM-9 transect at $40^{\circ} 20^{\prime} \mathrm{N}$. J. Geophys. Res., 105, 5859-5886. doi:10.1029/1999JB900301.

Eakin, D. H., K. D. McIntosh, H. J. A. Van Avendonk, L. Lavier, R. Lester, C.S. Liu and C.-S. Lee (2014). Crustal-scale seismic profiles across the Manila subduction zone: The transition from intraoceanic subduction to incipient collision. J. Geophys. Res., 119, 1-17. doi:10.1002/2013JB010395.

Eldholm, O. and K. Grue (1994). North Atlantic volcanic margins: Dimensions and production rates. J. Geophys. Res., 99, 2955-2968.

Gibbons A. D., Whittaker J. M., and Muller R. D., 2013. The breakup of East Gondwana: Assimilating constraints from Cretaceous ocean basins around India into a best-fit tectonic model. J. Geophys. Res., 118, 808-822.

Hsu, S.-K., Y.-C. Yeh, W.-B. Doo and C.-H. Tsai (2004). New bathymetry and magnetic lineations in the northernmost South China Sea and their tectonic implications. Mar. Geophys. Res., 25, 29-44. doi:10.1007/s11001-005-0731-7.

Lester, R., H. J. A. Van Avendonk, K. McIntosh, L. Lavier, C.-S. Liu, T.-K. Wang and F. Wu (2014). Rifting and magmatism in the northeastern South China Sea from wide-angle tomography and seismic reflection imaging. J. Geophys. Res., 119, 2305-2323. doi:10.1002/2013JB010639.

Maus, S., U. Barckhausen, H. Berkenbosch, N. Bournas, J. Brozena, V. Childers, F. Dostaler, J. D. Fairhead, C. Finn, R. R. B. von Frese, C. Gaina, S. Golynsky, R. Kucks, H. Lühr, P. Milligan, S. Mogren, R. D. Muller, O. Olesen, M. Pilkington, R. Saltus, B. Schreckenberger, E. Thébault and F. Caratori Tontini (2009). EMAG2: A 2-arc min resolution Earth Magnetic Anomaly Grid compiled from satellite, airborne, and marine magnetic measurements. Geochem. Geophys. Geosyst., 10, Q08005. doi:10.1029/2009GC002471.

McIntosh, K., L. Lavier, H. van Avendonk, R. Lester, D. Eakin and C.-S. Liu (2014). Crustal structure and inferred rifting processes in the northeast South China Sea. Mar. Pet. Geol., 58, 612-626.

http://dx.doi.org/10.1016/j.marpetgeo.2014.03.012. 
McIntosh, K., H. van Avendonk, L. Lavier, W. R. Lester, D. Eakin, F. Wu, C.-S. Liu and C.-S. Lee (2013). Inversion of a hyper-extended rifted margin in the southern Central Range of Taiwan. Geology, 41, 871-874.

doi:10.1130/G34402.1.

Meissner, R. (1986). The continental crust: A geophysical approach.

International Geophysics Series, Academic Press, London, Donn, W.L. (Ed.), 34,417 p..

Muller, R. D., J.-Y. Royer and L. A. Lawver (1993). Revised plate motions relative to the hotspots from combined Atlantic and Indian Ocean hotspot tracks. Geology, 16, 275-278.

Rangin, C. and J.-C. Sibuet (2017). Structure of the northern Bay of Bengal offshore Bangladesh: Evidences from new multi-channel seismic data. Mar. Pet. Geol., 84, 64-75. doi:10.1016/j.marpetgeo.2017.03.020.

Ridley, V. A. and M. A. Richards (2010). Deep crustal structure beneath large igneous provinces and the petrologic evolution of flood basalts. Geochem. Geophys. Geosyst., 11, Q09006. doi:10.1029/2009GC002935.

Sandwell, D. T., R. D. Muller, W. H. F. Smith, E. Garcia and R. Francis (2014). New global marine gravity model from CryoSat-2 and Jason-1 reveals buried tectonic structure. Science, 346, 65-67. doi:10.1126/science.1258213.

Sibuet, J.-C., F. Klingelhoefer, Y.-P. Huang, Y.-C. Yeh, C. Rangin, C.-S. Lee and S.-K. Hsu (2016a). Thinned continental crust intruded by volcanics beneath the northern Bay of Bengal. Mar. Pet. Geol., 77, 471-486. http://dx.doi.org/10.1016/j.marpetgeo.2016.07.006

Sibuet, J.-C., Y.-C. Yeh and C.-S. Lee (2016b). Geodynamics of the South China Sea. Tectonophysics, 692, 98-119. doi:10.1016/j.tecto.2016.02.022.

Talwani, M., K. S. Krishna, M. Ismaiel and M. A. Desa (2017). Comment on a paper by Sibuet et al. (2016) entitled "Thinned continental crust intruded by volcanics beneath the northern Bay of Bengal”. Mar. Pet. Geol., 
http://dx.doi.org/10.1016/j.marpetgeo.2016.12.009.

Wang, K.-L., Y.-M. Lo, S.-L. Chung, C.-H. Lo, S.-K. Hsu, H.-J. Yang and R. Shinjo (2012). Age and geochemical features of dredged basalts from offshore SW Taiwan: The coincidence of intra-plate magmatism with the spreading South China Sea. Terr. Atmos. Ocean. Sci., 6, 657-669. doi:10.3319/TAO.2012.07.06.01(TT).

White, R. S., D. McKenzie and K. O'Nions (1992). Oceanic crustal thickness from seismic measurements and rare earth element inversions. J. Geophys. Res., 97, 19683-19715.

White, R. S., L. K. Smith, A. W. Roberts, P. A. F. Christie, N. J. Kusznir and the rest of the iSIMM Team (2008). Lower-crustal intrusion on the North Atlantic continental margin. Nature, 452, 460-464. doi:10.1038/nature06687.

Whittacker, J. M., S. E. Williams and R. D. Muller (2013). Revised tectonic evolution of the Eastern Indian Ocean. Geochem. Geophys. Geosyst., 14(6), 1891-1909, Suppl. doi:10.1002/ggge.20120.

Zhao, F., T. M. Alves, S. Wu, W. Li, M. Huuse, L. Mi, Q. Sun and B. Ma (2016). Prolonged post-rift magmatism on highly extended crust of divergent continental margins (Baiyun Sag, South China Sea). Earth Planet. Sci. Lett., 445, 70-91. http://dx.doi.org/10.1016/j.epsl.2016.04.001.

\section{Legend of figures}

Figure 1: a) Location of the three wide-angle and reflection seismic profiles collected during the Bay of Bengal cruise (Sibuet et al., 2016a). Red dots are locations of the nine OBSs on each refraction profile. b) Free-air gravity map of the northeastern SCS showing MCS lines and refraction lines OBS2001, MGL905-20, T1 and T2 (black lines) with locations of OBSs (red dots) (Sibuet et al., 2016b). Numbers in red are OBSs numbers along OBS2001 line. White lines, bathymetric contours every kilometer. LRTPB, Luzon-Ryukyu transform plate boundary (thick black line). The thinned continental crust intruded by volcanics (McIntosh et al., 2013; Eakin et al., 2014; Lester et al., 2014; 
McIntosh et al., 2014; Sibuet et al., 2016b) is located north of the Continentocean transition (COT, dashed purple line). Magnetic lineations 15 to 17 identified by Hsu et al. (2004) as oceanic chrons are in fact lower Miocene postspreading volcanic ridges. Black crosses and dashed black lines, elongated volcanic intrusions and depressions respectively. Number 12 and lower numbers in black are oceanic chrons 12 and younger. DF, Deformation front. White star is the dredge where a 22 Ma old E-type MORB basalt was founded (Wang et al., 2012).

Figure 2: 1-D velocity-depth profiles (thin black lines) every ten kilometers for the three profiles (a, b and c) located in Figure 1a (Sibuet et al., 2016a). Crustal velocities are assumed to start at the top of the crust. Velocity bounds for 59-27 Ma old oceanic crust in light blue (White et al., 1992) and for exhumed, serpentinized upper mantle in dark blue (Dean et al., 2000). The thick grey line is the mean velocity crust for extended continental crust (Christensen and Mooney, 1995). d) 1-D colored velocity-depth profiles associated with several plumes (Ridley and Richards, 2010). NAVP, North Atlantic volcanic province.

Figure 3: (a) P-wave velocity-depth profiles along lines OBS2001 (OBSs 1 to 11), MGL905-20 (1-D velocity profile from the distal margin, thick black line) and MCS stack velocities (in blue) from portions of MCS lines located in the deep domain located north of the COT (Figure 1b) adapted from Sibuet et al. (2016b). P-wave velocity models along profiles MGL905-20 (b) and OBS2001 (c). A, B, C and D are buried or outcropping volcanic ridges. d) Crustal structure along MCS profile MGL0905-10 adapted from McIntosh et al. (2014) (depth converted image) located in Figure $1 \mathrm{~b}$ (continuous and dashed lines). Rotated normal fault blocks of the upper crust are well imaged and there is a large amount of intra-crustal reflectivity marking an apparent detachment zone and also the top of high velocity lower crust (HVLC) in places. The HVLC located below the detachment fault, appears to be relatively thin $(<2-5 \mathrm{~km})$. e) Crustal structure along MCS profile MGL0905-10 adapted from Sibuet et al. (2016b) located in figure $1 \mathrm{~b}$ (continuous portion of line) showing that the intruded volcanic feature was emplaced after rifting ceased. DF, Deformation front. 


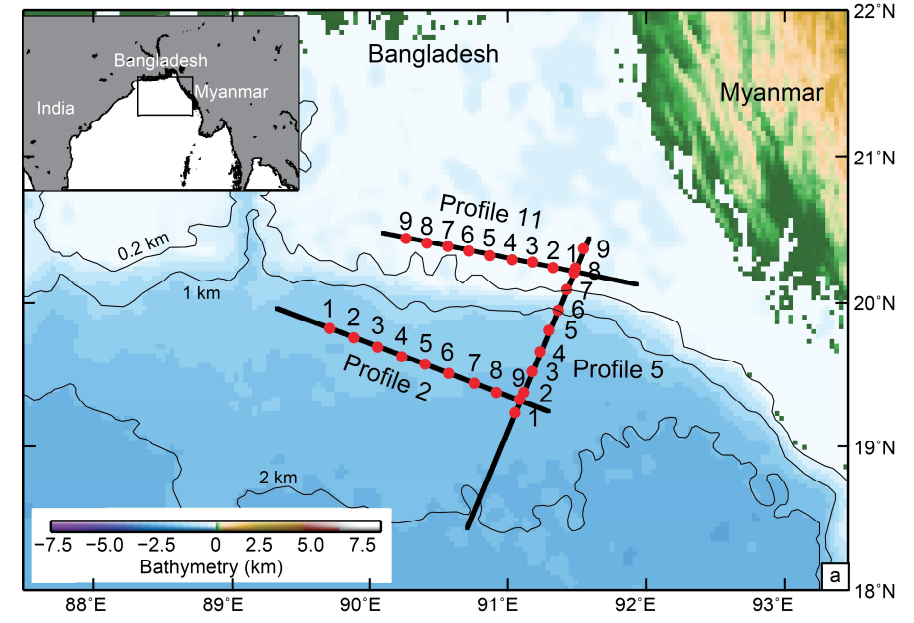

Figure 1 Revised (Sibuet et al.)

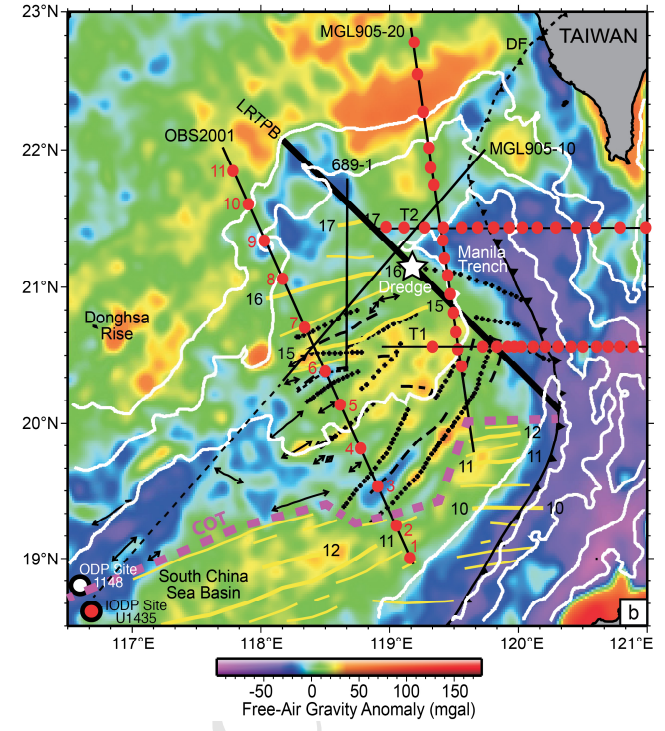



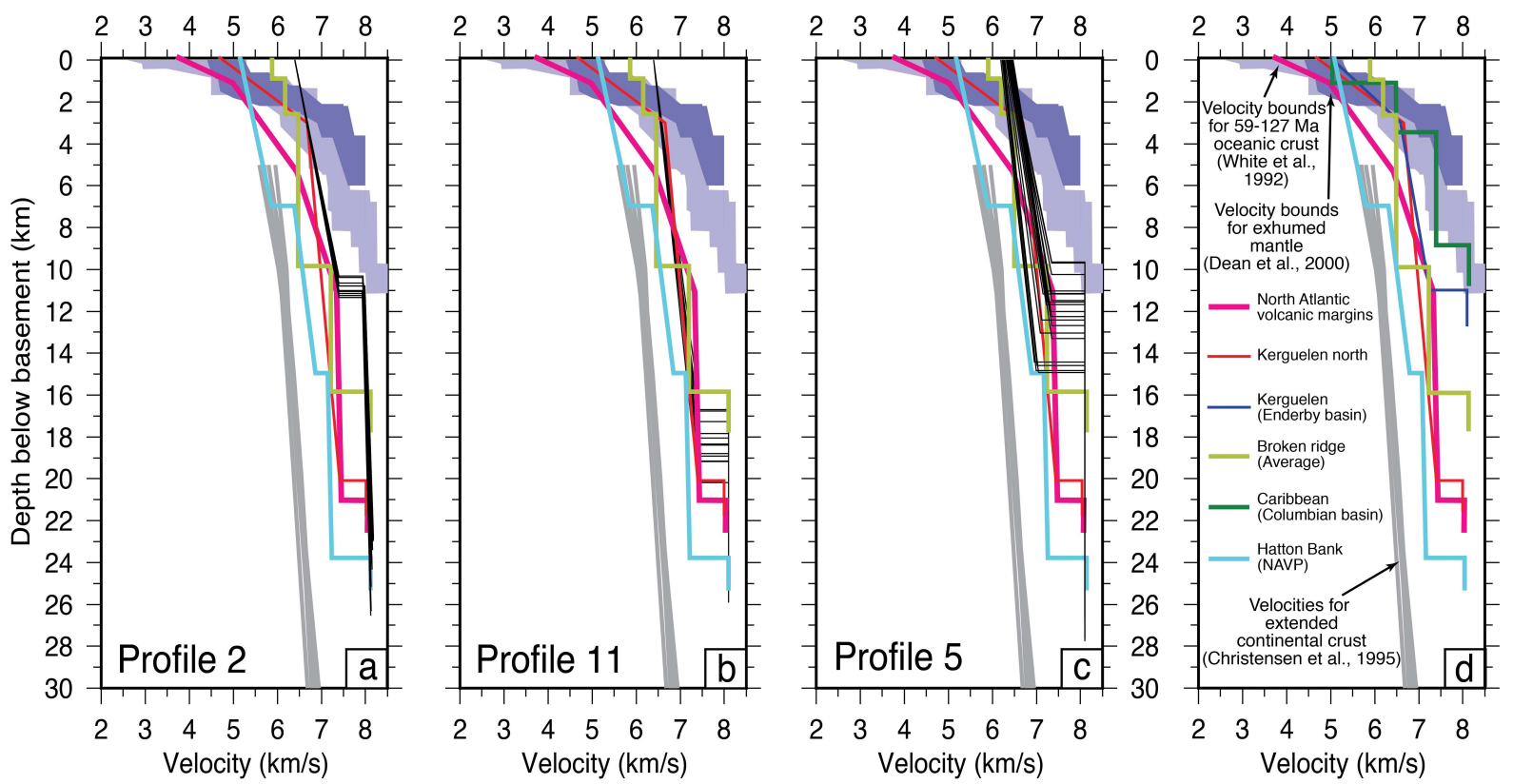

Figure 2 Revised (Sibuet et al.) 

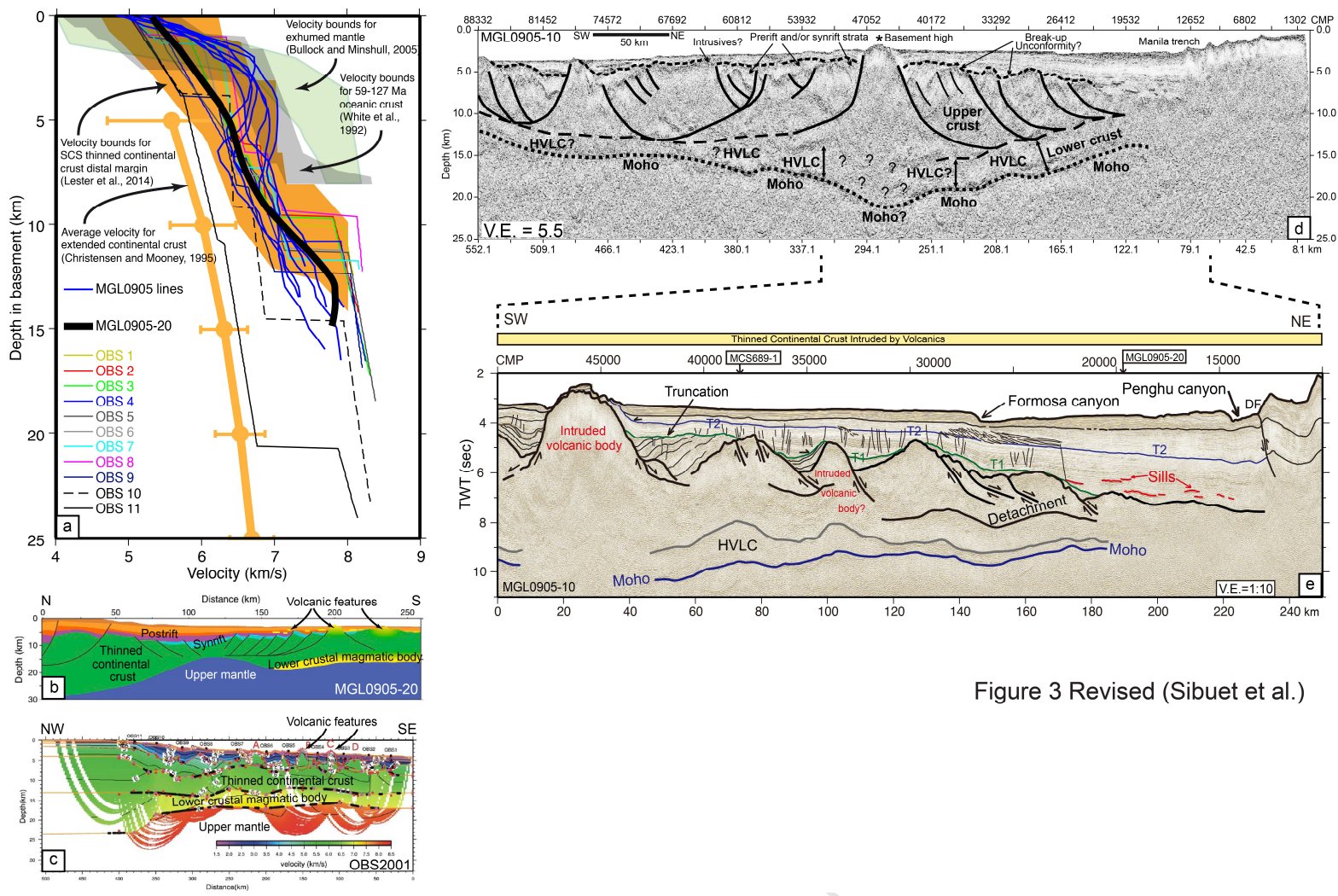

Figure 3 Revised (Sibuet et al.) 